\title{
Challenges and Pitfalls of Feminist Sisterhood in the Aftermath of the Cold War ${ }^{*}$ The Case of the Network of East-West Women
}

\author{
loana Cîrstocea (CNRS, CESSP, Paris)
}

\begin{abstract}
Established in the aftermath of the Cold War and animated by US-based scholars and activists experienced in the second wave of women's liberation movements, the Network of East-West Women (NEWW) has received little attention from scholars. This transnational and transregional group played an instrumental role in triggering and structuring the circulation of information, contacts, and academic and activist publications dedicated to women in Central and Eastern Europe, and in conceptualizing new gender politics in that region after the end of the socialist regimes. Building on original empirical evidence (archive work and interviews), this article considers NEWW's founding and its steps in establishing operations "beyond borders" in the 1990s-a time of professionalizing and globalizing women's rights politics when transnational feminist activism was faced with both new challenges and potentialities.
\end{abstract}

KeYwords: feminism, Network of East-West Women, NGOs, post-Cold War, postsocialist Eastern and Central Europe, transnational solidarities

\section{Introduction: A Sui Generis Actor in Transnational Feminism}

The Network of East-West Women (NEWW), a transnational feminist group established in New York City in the aftermath of the Cold War, played an instrumental role in debating women's rights in Eastern and Central Europe (ECE) during the 1990s and the 2000s. ${ }^{1}$ Starting in 1990, NEWW founding members-a small nucleus of US-based feminist scholars and activists experienced in the second wave of women's liberation movement-came together to discuss the changing situation of women in the former socialist countries. They organized private meetings, lectures, and ad hoc gatherings to help ECE visiting scholars navigate US academic milieus. The group also compiled and circulated information, organized a telephone tree, and maintained an address 
book of women activists. After its official launch in the summer of 1991, the network gradually institutionalized itself: the International Steering Committee (ISC) was created in 1993, the NEWW association was incorporated in 1995 in Washington DC, and a Polish chapter was founded in 1999. In 2004, NEWW's international headquarters were transferred to Gdańsk, Poland, where it became NEWW-Polska. Connected to dozens of national and international human rights and feminist groups, this NGO endorsed the gender mainstreaming-related agendas promoted by the European Union and the United Nations.

NEWW developed a genuine feminist community, created a space for transatlantic and regional dialogue, and became a hub for the circulation of information, contacts, and academic and activist publications dedicated to gender politics in the ECE region and beyond. Numerous women's groups that emerged in the 1990s in the postsocialist countries benefited from its grants and fellowships, know-how, technical assistance, library and teaching resources. Hence NEWW's impetus has been highly instrumental in both the politicization of women's issues and the establishment of gender studies in the region. ${ }^{2}$ NEWW's experiences and challenges in building its East-West network have been reflected in numerous publications on gender and postsocialism in the region, some of which have been authored by NEWW members themselves. ${ }^{3}$

The network is a genuine embodiment of transnational feminist solidarity understood as a "praxis," defined by Dominique Masson and Anabel Paulos as the "active linking together of hitherto geographically and/or socially distant and disparate place-based struggles through the construction of connections between actors, places and mobilizations." ${ }^{4}$ Yet, despite intense and multifaceted activities, and publications by its own members and collaborators, NEWW remains outside the focus of both the history and sociology of transnational feminist movements. Its small size, its loosely structured activities, and its geographic scope might account for the omission of the network from the wide literature centered on women's activism "beyond borders" 5 published over the last decades. Ignoring both East-West dynamics and the former Second World (i.e., the countries of the former socialist "bloc"), ${ }^{6}$ scholars of women's activism have indeed systematically privileged the study of mobilizations structured according to a postcolonial North-South axis and that are often rooted in development cooperation programs.

Focusing on the network's early history, this article, based on interviews with NEWW's founders and archival work-including members' correspondence, NEWW publications, and notes and reports from meetings-outlines the steps in establishing the organization and examines the potentialities of post-Cold War feminist internationalism. It also sheds light on the social and political mechanisms involved in the international circulation of ideas, discourses, and activist practices ${ }^{7}$ during the first postsocialist decade.

The 1990s was a time of professionalizing in feminist activism, ${ }^{8}$ of globalizing women's rights and gender equality agendas, ${ }^{9}$ but also of increasing criticisms of universal claims in feminism. ${ }^{10}$ Shaped by and reflecting all these shifts, NEWW's experience offers insight into complex aspects of feminist organizing, such as: the challenges of practicing political solidarity beyond geographical and geopolitical borders and in spite of cultural differences or structural inequalities; the mechanisms involved in 
the formalization and the bureaucratization of women's rights politics; and the cooptation of critical actors and ideas in wider ideological streams, such as democratization and Europeanization, but also neoliberal globalization. ${ }^{11}$

\section{NEWW Builders and Original Impetus}

The US-based pole of what would become NEWW took shape around Ann Snitow (1943-2019), a professor of literature and gender studies at the New York Eugene Lang College of Liberal Arts (New School for Social Research, NSSR) and a well-known US radical feminist and pacifist activist. Her colleagues saw her as "a powerful figure," "a brilliant organizer," "the real force behind the network," and "a feminist powerhouse." ${ }^{12}$ Snitow was raised in an educated Jewish middle-class family of ECE descent and of left-wing political orientation. ${ }^{13}$ She earned her $\mathrm{PhD}$ in literature from the University of London (1978) and pioneered women's studies at Rutgers University and NSSR. She coauthored a series of popular books on feminist politics, contributed to numerous magazines and journals, and hosted one of the first feminist radio shows in the US. ${ }^{14}$ The collapse of socialist regimes and the end of the Cold War provided her with a new opportunity for feminist engagement and political reflection. The undergoing democratization processes revived both her interest in understanding women's lives under socialism and her willingness to scrutinize the postauthoritarian "transitions" through the lens of her experience in the Western women's liberation movement.

Snitow was supported by people sharing her political leaning and activist history, especially scholars in women's and gender studies or specialists of ECE, also interested in the region due to their family roots, memories of exile, and personal politics. Among them are Nanette Funk (born in 1942), a US radical feminist and a philosophy professor at Brooklyn College (City University of New York) specializing in German studies and active in Marxist feminist groups since the $1970 \mathrm{~s},{ }^{15}$ and Sonia Jaffe Robbins (born in 1942), then an associated scholar at New York University, holder of a degree in literature and journalism, a feminist activist, and a "red-diaper baby."16 For these US-based feminist activists, their involvement in transatlantic activity was rooted in complex mechanisms combining personal and political logics that reflected the specific conditions of the (post) Cold War era. They shared a vision of the Iron Curtain's collapse as an impetus for taking political action, testing and practicing their ideas, trying to inject feminism at the very basis of the new postsocialist democracies, while also nourishing their professional and political selves. For some of them, exchanging with women from ECE was a way of confronting their leftist commitment with the lived experiences of socialist regimes.

On the Eastern European side, Slavenka Drakulić was the counterpart of Ann Snitow in founding NEWW. Born in 1949 in a Yugoslav elite family, she was trained in sociology and literature, ${ }^{17}$ wrote several books, contributed to magazines, and participated in a group of feminist scholars, artists, and journalists established in the late 1970s. She was involved in the organization of an international feminist conference held in Belgrade in 1978, and she had an international visibility thanks to her publishing activities. ${ }^{18}$ In 1990, Drakulić was the American Ms. magazine's special correspon- 
dent in ECE, and she wrote an extensive report based on interviews with women from the former socialist countries. The documentary material collected then was a useful information source for US feminists involved in organizing NEWW, who contacted some of her interviewees.

Joanna Regulska (born in 1951) was also a key contributor in structuring NEWW. A Polish-born geographer, she emigrated in the early 1980s and began an academic career in the United States, where she was involved in founding women's studies programs at Rutgers University. ${ }^{19}$ In the late 1980s, she organized academic visits there for women scholars coming from ECE. Intended to support developing women's studies courses and research, these operations appear retrospectively as a genuine form of transnational activism, ${ }^{20}$ and she sees her very involvement with NEWW as a way of reconciling the split identity of exile. Her double cultural and social experience was a precious building block for feminist networking. ${ }^{21}$

In sum, NEWW's founders from both the West and the East were experienced activists established in the cultural professions. Their transnational political "praxis" entangled post-Cold War geopolitics with family histories and personal biographies.

NEWW's initiative originated in the Socialist Scholars Conference held in New York City in 1990, ${ }^{22}$ when Slavenka Drakulić made a polemic statement denouncing the economic shortages under state socialism and stressed their effects on women's everyday lives. In reaction to it, radical US feminists in the audience took the initiative of convening with women from ECE in order to learn more about their gendered experiences and to share ideas. After a series of meetings and spirited exchanges of correspondence during the summer of 1990, the US-based nucleus of NEWW came out with an invitation:

We were reading with alarm about possible loss of abortion rights, high rates of women's unemployment, and women's lack of representation in the new governments. ... Our goals are: first, to make an Eastern European dialogue across national boundaries about feminism and, second, to describe our own experience of developing a women's liberation movement-our successes and above all our failures to win things for women in a market economy. ${ }^{23}$

Depicted by the organizers as the "first East-West women's encounter," 24 an international conference marked the official launch of the network: several dozen women met in Dubrovnik ${ }^{25}$ between 7 and 9 June 1991, with the largest representation from the United States (19) and Yugoslavia (21). Among them were women activists who were to be present for a long time on the political and intellectual scenes of the ECE countries as well as in international human and women's rights arenas.

Snitow introduced the meeting, stressing the importance of international feminist solidarity in supporting and inspiring activists located in various national contexts. In her keynote speech, titled "Democracy without Women Is Not Democracy," Drakulić described women's situation in the former socialist countries using statistical figures. Both speakers emphasized the potential of "sisterhood," seen as the shared ground of women's condition in spite of different origins and experiences, as well as the necessity of building alliances across borders to make their political claims heard. Gloria Steinem, editor in chief of Ms magazine, addressed a letter to the "East-European 
sisters," including also greetings from Robin Morgan, editor of several anthologies of women's writings on "sisterhood." ${ }^{26}$ Highly symbolic, the involvement of these two iconic and internationally known figures of the US second-wave women's liberation movement was an expression of their interest in the event, as well as of their political support to ECE women.

The conference program included several thematic sessions, workshops, and consciousness-raising groups on family, work, sexuality and reproductive health, political participation and representation, models for feminist organizing, and strategies for establishing women's studies. The format of the gathering was flexible, allowing ample space for informal discussions. Not everything worked out as expected and some of the sessions did not have any attendees, for instance, one dedicated to labor issues and moderated by a former union leader. ${ }^{27}$ The consciousness-raising group-a classical component of US feminist workshops, recommended by the conveners as a connecting tool-shocked some of the ECE participants, who found it intrusive and rejected discussing private life experiences in front of strangers. ${ }^{28}$ Being accustomed to formal meetings, some also mocked the casual discussions as not serious enough. ${ }^{29}$ Such incidents heralded what would be identified in later exchanges and scholarship as an "East-West cultural clash." ${ }^{130}$ Interviewees also recalled their astonishment when encountering an unexpected "otherness" and discovering the Eastern European women's resistance toward the idea of women's common identity and struggles beyond their different political cultures and experiences.

The conference closed with a discussion of the next steps, many of which NEWW quickly realized: setting up a pressure group with the United Nations; creating a database of contacts and compiling a collection of publications on women's issues in the former socialist countries; establishing the infrastructure necessary to maintain connections across borders, exchanging information and building collaboration; publishing a regular newsletter and country reports on women's issues; disseminating classic Western feminist literature among ECE audiences; putting in place grants and internships for women activists and academics from ECE; helping establish women's studies centers, programs, and professional associations in the region; and collaborating with international programs already present there. ${ }^{31} \mathrm{~A}$ statement adopted at the end of the meeting and widely circulated thanks to the journalists who covered the conference summarized these points and stressed NEWW's ambition to contribute to the "development of a grassroots women's movement" in ECE. Ann Snitow reformulated the idea in a letter sent to the meeting participants on 28 June 1991: "Our priority is to develop communication systems across national lines.... I have a map of ECE on my wall and on hopeful days I see our Network as a series of proliferating lines drawn back and forth and everywhere, eroding borders, darkening into well-travelled roads." ${ }^{\prime 32}$

\section{Growing and Practicing Solidarity at a Distance}

In order to actualize its vision, NEWW engaged in an institutionalization process. After the conference, the US group started working on enlarging and consolidating the network. They publicized their activities and compiled a collection of "NEWW 
resources" (such as experts on the former Soviet bloc countries, or persons working on cultural projects related to the region), and they planned on translating and publishing feminist literature. ${ }^{33}$ In 1992, the first newsletters of NEWW were assembled and circulated, listing new feminist groups and initiatives taking place in various ECE countries. An invitation to join NEWW was also enclosed: "Dear Friend, if you have been thinking and worrying about women's changing situation in your country and the rest of ECE, we invite you to join the NEWW. . . If you are developing projects that might benefit by network support, please let us know. Let us keep alive Ann's vision of a proliferation of lines across the map of ECE." 34

Continuously reviewing the definition of the network's mission and profile, the founders hired an external expert to evaluate their activities from a managerial perspective. According to her report, the strengths of the group were its genuine combination of activists and academics, its stable international connections, and its involvement in ECE early after the political regime changes. Among its weaknesses were the loose format, the lack of hierarchy, the prevalence of English-speaking, USbased members, as well as the absence of any professional staff and of any practical program. To make the network credible from a funder's perspective, the consultant recommended that NEWW "find a clear niche that doesn't replicate other established groups and be driven by the Eastern women's needs." 35

This prospect was discussed in a series of board meetings, ${ }^{36}$ when heated debates turned around the practical running of NEWW. Some members pointed out the risk of Western women's patronizing behavior and the social and economic inequalities between NEWW's constituencies, while others emphasized the importance of "starting the process (of organizing) and beginning the dialogue." Correspondence from the same period also focused on NEWW's main operational and symbolic categories, namely, East and West, the perimeter of the target region, and the extent of transnational cooperation. The relevance of the label "West" - obviously too general given that all the Westerners in the network came from the US-was part of this reflection. ${ }^{37}$

Based on its core beliefs in the need for "interaction and cross-fertilization of ideas, "38 the US-based group continued to circulate news about women's organizations, feminist resource centers in ECE, international conferences, and publications. In order to gather up-to-date information about the social and political situation in ECE and to enlarge the constituency, they also regularly hosted people who had traveled to and from the region. These meetings were instrumental in raising awareness of sensitive issues concerning women's lives in the former socialist countries, such as new legislation threatening their rights.

The network rapidly became an essential source of information and contacts not only for feminist scholars but also for other professionals such as journalists, artists, and even political experts interested in reaching the region of ECE. By the end of 1993, the expanding demand had become impossible to manage within the means of a small informal group. Snitow describes this difficulty in a letter defending the necessity of fundraising and institutionalizing:

Dear Friends, Help! I started with a kitten, the idea of a network that would link feminists in the West with feminists in the new post-communist coun- 
tries, and when I turned around this little kitty was a big lion requiring a few pounds of raw meat a day. The NEWW seemed like a manageable idea but the growth of the thing-which is wonderful-is way but beyond our capacity to respond rapidly or well to all demands on our services. . . . We simply don't have a solid enough structure in place yet. This is the grow-or-die moment for the network. ${ }^{39}$

In further organizing the network, NEWW members built on a few core values, such as a firm "feminist identity" and "the belief that contact over borders is in itself a part of the freedom we seek." 40 Marjorie Lightman, a historian educated at Rutgers University and working since the late 1980s as a consultant for US nonprofit actors and government agencies, ${ }^{41}$ is recognized for formulating the group's hallmark, namely, an "international women's movement actor," a "lateral, mutually supportive, democratic communications network," "the opposite of an organization offering help to victimized women." 42

Over the following years, the formal organization of the group developed and membership kept growing. They opened an office in Washington DC under the practical leadership of Shana Penn (born in 1955, a historian of women's participation in the Polish Solidarity movement) ${ }^{43}$ who approached think tanks and government agencies in order to access funding. One of the emblematic programs of the network, the On-Line Initiative, ${ }^{44}$ was launched in the summer of 1994 with funding from the Eurasia Foundation, Ford Foundation, MacArthur Foundation, and World Learning. It allowed the opening of thirty-one email accounts for women's groups during its first wave, ${ }^{45}$ when two NEWW trainers traveled to ECE countries, touring the new feminist organizations located in the main cities and providing computer and internet tutoring to their members. The trainers recall that some of the beneficiaries of the program started at the level of "how to switch the computer on, how to use the mouse."46 Women newly connected to the internet emailed the NEWW office expressing their gratitude and enthusiasm: "This is really magic . . a technical witchcraft!" 47

By making available computers, internet technology, and training, the program implemented Snitow's vision of a map traversed by links connecting ECE women's groups with one another and globally, enabling them to know each other, exchange ideas, and collaborate. Importantly, it was established at a time of international momentum for women's rights and gender issues structured around the UN world conferences of the early 1990s, especially the 1995 Fourth World Conference on Women in Beijing. In the framework of the On-Line Initiative, NEWW created a general information service, the "women-east-west" mailing list, together with the "neww.beijing" listserv, dedicated to the Beijing event. Victoria Vrana, a US postgraduate student in literature and a computer technology apprentice hired by NEWW, ${ }^{48}$ was also present aboard the train run by the United Nations Development Program from Warsaw to China, where she provided training on computer and internet use to the travelers.

The On-Line Initiative also actualized NEWW's vision of nonhierarchical feminist organizing and politics. In the mid-1990s and after, computers and internet technology served as the main tools allowing a series of "online meetings" of the network's International Steering Committee (ISC) to take place. Via carefully planned email ex- 
changes deployed over several weeks, the participants from both East (sixteen) and West (three, plus nine observers) discussed the organization's governance and strategy for establishing democratic decision making. ${ }^{49}$ In starting the remote virtual meetings, moderator Sonia Jaffe Robbins dispatched a set of documents raising the issue of representation and consensus within the network and asking for suggestions about the future role and functioning of the coordinating committee, as well as the terms of the internal decision-making process.

Before entering the online debate, the participants were asked to introduce themselves in writing. Their short autobiographical narratives provide an insight into the transnational interactions, and they reveal the respective understanding of the "self" by women from the West and from the East. While the former shared mainly their activist experience and political accomplishments, the latter summed up their degrees, professional positions, official responsibilities, sometimes also their family lives. All the participants ended their messages with "In sisterhood," showing their appreciation of the shared identification as NEWW members.

The bylaws of the organization together with the modalities for choosing its representatives and designing its priorities were also discussed via email, each participant expressing her understanding of the ISC's role. Mihaela Miroiu, a feminist scholar in Romania, viewed this coordinating body as an "advisory group" and also as an "evaluator" of the projects submitted for funding under NEWW's label. Christina Kotchemidova of the Free Feminists in Bulgaria suggested it "help with shaping projects, offer guidelines" and "be open to projects coming from all NEWW members." Olga Lipovskaya, poet and feminist in Russia, was interested in "working together on international projects," and she urged the committee to be "generating ideas." Others suggested that the ISC "identify and contact donors," "disseminate information," and "encourage local activity." The idea of situated "needs analysis" to be carried out prior to launching any further NEWW programs was formulated in several emails. Activist Urszula Nowakowska of Poland stressed the importance of utilizing "local knowledge," tailoring "projects on local needs," and encouraging "local activity." Etela Farkašová of Slovakia explicitly expressed worries about the risk that the ISC "yield into a situation of dominance" and "hinder the free dialogue among participants." In a dispirited message, Rosica Panova of Bulgaria addressed the material inequalities separating NEWW members: "Our economy is collapsing. ... Bulgarian people [are] starving and trying ONLY to survive. ... Could the ISC projects and discussions be relevant to the people from Eastern Europe? Isn't the West too far from us?"

In their turn, the US-based participants acknowledged NEWW's delicate position as an organization located outside the ECE and, therefore, disconnected from its grassroots constituency: "The major generation of the proposals should come from the region, the people on the ground, they are best able to determine what is needed," stressed Mariama Williams, ${ }^{50}$ acknowledging in the meantime that "the ISC may be aware of wider macro-economic and global trends . . . more aware of general funding trends and currents which could be relevant to individual groups in different areas."

NEWW's concern with hegemony and with uneven symbolic and material resource distribution among its members from the East and from the West was to be continuously debated over the years. Asking the question, "How can NEWW be both 
democratic and realistic about the particular kind of contribution it can make to feminism in the [ECE] region?"51 the group brainstormed again in early 1997 about their vision of the network's identity, its mission, its priorities and its products, and its members' responsibilities and benefits. Faithful to an ethos of free association and reaffirming a steadfast refusal to formalize feminist politics too strongly, Snitow stuck at that time to the idea of a "Socratic" steering committee whose mission was to "raise questions about women's realities and the meaning of feminism in the [ECE] region."

Yet, less than two years later, facing an internal crisis and confronted by criticism from ECE members-some of whom saw NEWW merely as a "talking shop" and not more than "a moral support network" 52 - the core group relaunched remote consultations via email in order to identify practical ways of performing transatlantic feminism. They recognized "unstructured" work and the "odd relationship [of second-wave feminists] to expertise" as the main limitations of the network's activities in the previous years. ${ }^{53}$ The idea of developing "a second financial and administrative base in a country in the [ECE] region where staff and projects function" came out as a solution. ${ }^{54}$ Communicated to the members before the first face-to-face ISC meeting held in Warsaw in late 1998 , this decision marks the firm transformation of the loose network into a professionalized NGO. At the same time, NEWW's communication documents displayed new language-including "advocacy," "policy initiative," "strategic planning"55_and the agenda was clearly oriented toward the European Union's framing of gender equality.

Opening a chapter in Europe was not only a way of diminishing the distance between the network's operating headquarters and its ECE constituency, but also a pragmatic option intended to secure NEWW's access to EU resources. Poland was chosen as a location because of the links several members had to this country: Snitow had started teaching there in a NSSR program in the early 1990s; Regulska collaborated with Polish activists in various policy projects for which she raised international funds. The ECE chapter of the network was headed by Erin Barclay, a US attorney professionally acquainted with the Women's Rights Center in Warsaw. ${ }^{56}$ Later, Małgorzata Tarasiewicz, ${ }^{57}$ a gender issues expert in Poland, became the lasting leader of NEWW-Polska. In addition to her friendship with the NEWW US-based founders, Tarasiewicz had been involved in dissident movements during her youth and was familiar with international human rights milieus.

\section{Rethinking Feminism after State Socialism}

During the 1990s, animated by internationalist ideals and in an attempt to revive and extend their activist practice, NEWW founding members recast parts of the historical repertories of US second-wave women's liberation movements in ECE. Aimed at widening the post-Cold War mobilizations on women's rights through an "international conversation," their initiative also rekindled and rescaled their feminist politics by taking on projects "beyond borders." Even though many nonhegemonic voices-of women of color, lesbian, postcolonial citizens-had, by that time, criticized the idea of universal solidarity and community of fate unfolded by "sisterhood" as a mobilization framework, NEWW firmly stuck to it. The network's US-based founders embraced 
transnational women's solidarity as a powerful political tool and even as a resource for renewing democracy. As Snitow recalled, "[NEWW members] were radicals, [they] wanted post-communism to be a wonderful new period of time, of social activism, a time of opportunity and change. [They] were hopeless idealists, [they] had fantasies that this would be a moment of mass mobilization on what citizens wanted, what kind of society they wanted to have." 58

As envisioned by NEWW, transnational activism was by no means a one-way (West to East) transmission of ideas and preoccupations but a constant engagement with each other's experiences in order to identify a bottom line allowing for building feminist strategies. Having acknowledged the different, situated imaginaries of women's emancipation through their early encounters with women from ECE, and facing their counterparts' reluctance to endorse "ready-made" women's movement's issues and slogans, NEWW's Western members embraced the idea of multiply defined and locally rooted mobilizations for women's rights. For furthering them, they chose to hold onto a general, operational, and pragmatic principle, namely, to consider gender inequalities as an anthropological invariant differently shaped by social and political contexts, and to envision critical feminist politics accordingly. Far from imposing improbable universal solutions for women's issues, NEWW aimed at cultivating critical political sensitivity, "finding meaningful entry points for feminist thinking; finding what feminism needs to be in different situations; building feminist consciousness and politics; building an activist community; doing political interventions; work together in an international feminist movement." 59

The US-based initiators of NEWW viewed themselves as "enablers" of the new feminisms emerging in the former socialist countries, and they considered their activism as "empowering" politics. Such self-representations might well be naïve or presumptuous, but they expressed also those women's firm belief in the potentiality of "transversal politics" and "strategic solidarities" - two themes widely explored in scholarship dedicated to transnational activism. ${ }^{60}$ At the same time, NEWW builders did not ignore their own privilege as educated, middle-class citizens of a hegemonic state, nor the huge economic and technological gaps separating them from the women located in ECE, which, in the 1990s, appeared as a new global periphery. In 2014, Snitow reflected on the organization's intent and history: "There are a few written pieces about NEWW, some of them picture us as imperialist. It must have been true, but this is not the key. ... We were very unequal, but we didn't really know what to do."61

While taking into consideration power differentials and constantly debating them, NEWW stimulated a new feminist sensitivity. Through their attempts at nonhierarchical organizing and transparent group governance, its founding members actualized their political vision, despite structural inequalities of all kinds and rising postcolonial and intersectional criticisms in feminism. For reinventing and reworking "sisterhood" as a consistent political agenda, NEWW made pragmatic choices and endeavored to overcome the geopolitically rooted gaps among the women composing its constituency through sharing essential resources, such as books and teaching curricula, information technology and know-how, and political organizing skills and tricks.

Undoubtedly, US-based feminists involved in transatlantic and regional exchanges sometimes overlooked the heterogeneity of the postsocialist countries, mixing them 
under the unifying label of "the region" of ECE. They also contributed to "disciplining the Second World" ${ }^{\prime \prime 2}$ by disseminating liberal references and repertories that furthered the processes of ideological globalization. Yet, NEWW also decisively contributed to producing new feminist politics, and their activism was an example of what Masson and Paulos describe as a "generative process fostering the emergence of new political subjects." ${ }^{\prime 63}$ Dialoguing with Westerners, women from the ECE region repeatedly refused to endorse the political mobilization themes identified by the US feminists, and they vividly criticized the ignorance, the patronizing attitudes, and the ethnocentric (or even orientalist) thinking of their counterparts. ${ }^{64}$ In the meantime, transnational encounters called into discussion the socialist emancipation projects: acknowledging the limits of the former regimes' gender policies, language, and ideology, postsocialist feminists also revalued and endorsed their accomplishments in women's rights and family policies matters. ${ }^{65}$

Whatever their ideological stance toward the socialist regimes, women from ECE used the transatlantic "conversations" for building a common voice and for claiming their distinct political identity in the post-Cold War global venues of women's rights. First used by the NEWW founders to refer to the area targeted by their activist projects, the descriptive category "East European" was eventually endorsed as a premise of collective identification by ECE feminists and gender experts taking part in international debates. Proudly claiming to be "Second World women," some of these actors expressed their awareness and also their criticism of the global political rearrangements of the 1990s. One of the most striking occurrences of such sensitivity is the "Statement from the Non-Region" delivered during the 1995 Beijing conference in the name of women from the former Soviet "bloc" by the representative of an "East-East caucus." Written by ECE activists previously connected in the framework of NEWW, the document criticized the invisibility of the "countries in transition" on the world conference's agenda and appealed to international organizations' support in order to tackle the social and economic challenges generated by the postsocialist liberalization processes.

Transatlantic networking was highly instrumental in inspiring, training, and legitimating feminist professionals based in the former socialist countries, as well as to opening international women's rights advocacy venues to them. The growing numbers of publications by now internationally renowned ECE gender experts-who benefited from international socialization and whose early work NEWW supported and helped make visible - their participation in conferences, their teaching and research activities in their home countries and abroad, and their work within organizations such as the $\mathrm{UN}$ and the EU agencies illustrate this better than any other account. Dozens of years after the launching of NEWW, feminists from ECE continue practicing "solidarity in struggle ${ }^{\prime \prime 67}$ as far as gender equality issues are concerned in their societies.

\section{Conclusion: Generations of Women's Rights Activism}

During the 1990s, NGOs took over informal groups, in feminist politics and more broadly, in the ECE region and beyond. Supported by international organizations and promoted in the postsocialist countries as democratization tools or "seeds of civil soci- 
ety," NGOs-deemed primary agents of neoliberal globalization by critical social scientists-became privileged political mediators. Contrasting with grassroots activism, their agendas as well as their practices were shaped by bureaucratic routines and by donors' priorities. ${ }^{68}$

NEWW's experience of institutionalization and relocation illustrates well this turnover in feminist organizing and the general change in the forms of women's rights activism during the post-Cold War years. Throughout less than a decade, the network, which was initially a grassroots initiative, transformed into an institution. Its evolution-the move to Eastern Europe, the firm identification as an expertise provider and as a professional actor in the field of women's and human rights advocacy, the attachment to EU gender equality agendas-shows that a historical page was turned. Still, devoted to its original project, NEWW remained small compared to other women's rights organizations, as its salaried staff never exceeded a few persons and its mission continued to be that of a "clearing house for feminist information," with a few million hits on its website monthly. ${ }^{69}$

Members of a political generation rooted in the second-wave movements for women's liberation and true to their historically built anti-institutional ethos, the US-based radical feminists who created the network were waved off the frontline by the institutionalization of NEWW. The rapid evolutions of the political landscape challenged their attempt at practicing "Socratic" feminism and loosely structured transnational networking. In order to remain politically active and to access funds allowing their "praxis" to unwind, the growing group was obliged to transform into a clearly legible format and meet the general conditions and references circulating in the "civil society" grant market. Becoming experts and recommending themselves as such was not an easy metamorphosis for the NEWW founders, "historical" feminists reluctant to bureaucratize and keen on preserving a free form of association. Some of them considered fundraising, external evaluations of their activities, professional management, and accountability as odd constraints. ${ }^{70}$ When it outgrew its informal capacities and when its early activist resources proved to be insufficient, the network needed help in order to establish itself as a credible organization. Then, external consultants and staff hired to hold specific management positions connected the first layer of experienced-but somehow "out-of-fashion"-feminist activists with the "democracy makers" ${ }^{\prime 71}$ and with the international bureaucracies supporting women's and human rights. Equipped with specific technical and professional skills, a younger generation helped soften the "culture clash" between the second-wave radical activists and these institutional milieus.

Undergoing significant changes and learning "by doing," NEWW successfully managed transitioning to the "NGO age" of feminist politics. Eventually, the critical project of the founders was handed down to a new generation of women's rights activists and gender experts established in the ECE countries during the 1990s. Tarasiewicz, NEWW's Polish leader, herself belongs to and practically embodies this cohort, which became visible with the very support of the network and was socialized through the East-West exchanges that shaped the political environment of the postsocialist transformation years. However, even if the network's founders withdrew from the forefront when the time of genuine unstructured activism ended, the strong emotional links on 
which the group built itself remained vivid. Friendships and common experiences composing a powerful feminist genealogy continued feeding both the organization's later activities and its institutional memory. As Ann Snitow put it, "[they] all breathe into each other's lives now."72

Untangling this multilayered history and complementing previous scholarship dedicated to analyzing the concrete practices of transnational feminism, this article puts the Network of East-West Women back on the map of women's movements "beyond borders." Added to the existing literature focusing mainly on North-South and less on South-South and East-South geographies, the East-West case studied here may help further comparative work and the general understanding of the social and political dynamics shaping transnational women's rights activism in various historical periods and geopolitical contexts.

\section{$\diamond$ About the Author}

Ioana Cîrstocea is a sociologist at the French National Center for Scientific Research (CNRS) and a member of the European Center for Sociology and Political Science (Centre européen de sociologie et de science politique, CESSP) in Paris. Her research mainly deals with the sociology of intellectual spaces and with the production and circulation of feminist knowledge in transnational (post) Cold War settings. Her most recent published works include La fin de la femme rouge? Fabriques transnationales du genre après la chute du Mur [The end of the red woman? (Re)making gender transnationally after the Cold War] (Rennes: Presses Universitaires de Rennes, 2019); and (edited with Delphine Lacombe and Elisabeth Marteu), The Globalization of Gender: Mobilizations, Frameworks of Action, Knowledge (London: Routledge, 2019).

\section{$\diamond$ Notes}

*In loving memory of Ann Snitow (1943-2019), founder of the Network of East-West Women.

1. Arguments synthesized here were first presented at the conference "Women of the World: Women's International Activism in National Contexts from 1945 until Now" (Paris, CRIDAF, 18 November 2011), and the proceeding was uploaded on the HAL-SHS platform: https://hal .archives-ouvertes.fr/hal-00987413/document. The present article is part of a larger projectIoana Cîrstocea, La fin de la femme rouge? Fabriques transnationales du genre après la chute du Mur [The end of the red woman? (Re)making gender transnationally after the Cold War] (Rennes: Presses Universitaires de Rennes, 2019) — for which I conducted fieldwork between 2006 and 2016, supported by several institutions. I warmly thank all of them here: the Central European University Budapest (Gender Department, Visiting Scholars Program), 2008; the French-American Fulbright Commission (Chercheurs Program) and the Institute for Research on Women at Rutgers University (Visiting Scholars Program), 2010; the French National Center for Scientific Research (CNRS) and the Center for European and Mediterranean Studies at the New York University (Soutien à la mobilité internationale des chercheurs), 2014; Agence Nationale de la Recherche (GLOBALGENDER), 2013-2016; CEFRES-Centre français de recherche en sciences sociales Prague (Aide à la mobilité internationale des chercheurs), 2016. I am grateful to Sébastien Le Pipec (EHESS, Paris) for helping me edit this article and to Aspasia's anonymous reviewers and editors for insightful comments and questions on earlier versions. My deep grat- 
itude goes to all the NEWW members who answered my interview requests and facilitated my work. I am particularly indebted to Ann Snitow: the documents referred to here come from her archives, including correspondence, notes from NEWW gatherings, reports, and publications. Given the sources, the perspective on the East-West feminist debates of the 1990s might look unbalanced. For further elements on their contents, on their social conditions, as well as on the specific positions of women based in ECE, please refer to my monograph mentioned above (especially part 3, "Sociographie des 'pionnières' est-européennes du genre").

2. See Cîrstocea, La fin de la femme rouge? for a detailed sociological account of this process. See also Krassimira Daskalova, Mihaela Miroiu, Agnieszka Graff, Tatiana Zhurzhenko, Marina Blagojevic, Judith Acsády, "Forum: The Birth of a Field. Women's and Gender Studies in Central, Eastern and South-Eastern Europe," Aspasia: The International Yearbook of Central, Eastern and South East European Women's and Gender History 4 (2010), 155-205, https://doi.org/10.3167/ asp.2010.040110; Krassimira Daskalova, ed., "Forum: The Birth of a Field: Women's and Gender Studies in Central, Eastern and Southeastern Europe, Part II," Aspasia. The International Yearbook of Central, Eastern and South East European Women's and Gender History 5 (2011), 128-203, https:// doi.org/10.3167/asp.2011.050109; Susan Zimmermann, "The Institutionalization of Women and Gender Studies in Higher Education in Central and Eastern Europe and the Former Soviet Union: Asymmetric Politics and the Regional-Transnational Configuration," East Central Europe/ ECE 34-35, nos. 1-2 (2007-2008), 131-160, https://doi.org/10.1163/18763308-0340350102007.

3. See, among others, Nanette Funk, "Feminism East and West," in Gender Politics and Post-Communism: Reflections from Eastern Europe and the Former Soviet Union, ed. Nanette Funk and Magda Mueller (New York: Routledge, 1993), 331-337; Laura Busheikin, "Is Sisterhood Really Global? Western Feminism in Eastern Europe," in Ana's Land: Sisterhood in Eastern Europe, ed. Tania Renne (Boulder, CO: Westview Press, 1997), 12-21; Joan Wallach Scott, Cora Kaplan, and Debra Keats, eds., Transitions, Environments, Translations. Feminism in International Politics (New York: Routledge, 1997); Jasmina Lukić, Joanna Regulska, Darja Zaviršek, eds., Women and Citizenship in Central and Eastern Europe (Aldershot, UK: Ashgate, 2006).

4. For this definition, I refer to Dominique Masson and Anabel Paulos, "Solidarity-Building as Praxis: Anti-Extractivism and the World March of Women in the Macro-Norte Region of Peru," in Cross-Border Solidarities in 21st Century Contexts: Feminist Perspectives, ed. Janet Conway, Pascale Dufour, and Dominique Masson (in progress, papers of the international symposium "Transnational Objects, Activist Solidarities, Feminist Analytics," Ottawa, Ottawa University, 5-7 December 2018).

5. Cf. Margaret E. Keck and Katheryn Sikkink, Activists beyond Borders: Advocacy Networks in International Politics (Ithaca, NY: Cornell University Press, 1998).

6. See Janet M. Conway, "Troubling Transnational Feminism(s): Theorising Activist Praxis," Feminist Theory 18, no. 2 (2017), 205-227, https://doi.org/10.1177/1464700117700536. The latest overview of transnational feminist movements, Rawwida Baksh and Wendy Harcourt, eds., The Oxford Handbook of Transnational Feminist Movements: Knowledge, Power and Social Change (New York: Oxford University Press, 2015), ignores not only NEWW, but also the Second World in general, as well as the international initiatives catalyzed by socialist organizations during the Cold War. On the latter topic, see Kristen Ghodsee, Second World, Second Sex: Socialist Women's Activism and Global Solidarity during the Cold War (Durham, NC: Duke University Press, 2019), and Francisca De Haan, "Continuing Cold War Paradigms in the Western Historiography of Transnational Women's Organizations: The Case of the Women's International Democratic Federation (WIDF)," Women's History Review 19, no. 4 (2010), 547-573, https://doi.org/10.1080/09 612025.2010 .502399$.

7. Pierre Bourdieu, "Les conditions sociales de la circulation internationale des idées" [The social conditions of the international circulation of ideas], Actes de la recherche en sciences sociales 
145 (2002), 3-8, https://doi.org/10.3917/arss.145.0003; Johanna Siméant, “La transnationalisation de l'action collective" [Collective action goes transnational], in Penser les mouvements sociaux [Thinking social movements], ed. Éric Agrikoliansky, Isabelle Sommier, Olivier Fillieule (Paris: La Découverte, 2010), 123-143.

8. On the "NGO-ization" and professionalization of feminist politics, see Sabine Lang, NGOs, Civil Society, and the Public Sphere (New York: Cambridge University Press, 2013); Victoria Bernal and Inderpal Grewal, eds., Theorizing NGOs: States, Feminisms, and Neoliberalism (Durham, NC: Duke University Press, 2014); see also Petra Meier and David Paternotte, eds., La professionnalisation des luttes pour l'égalité des sexes [The professionalization of gender equality struggles] (Louvain-la-Neuve, Belgium: Académia L'Harmattan, 2017).

9. Nancy Naples and Manisha Desai, eds., Women's Activism and Globalization: Linking Local Struggles and Transnational Politics (London: Routledge, 2002); Valentine Moghadam, Globalizing Women: Transnational Feminist Networks (Baltimore: Johns Hopkins University Press, 2005); Myra Marx Ferree and Aili Mari Tripp, eds., Global Feminism: Transnational Women's Activism, Organizing and Human Rights (New York: New York University Press, 2006); Pascale Dufour, Dominique Masson, Dominique Caouette, eds., Solidarities beyond Borders: Transnationalizing Women's Movements (Vancouver: UBC Press, 2010); Baksh and Harcourt, The Oxford Handbook of Transnational Feminist Movements; Delphine Lacombe, Elisabeth Marteu, Anna Jarry-Omarova, Brigitte Frotiée, eds, "Le genre globalisé" [Globalized gender], thematic issue, Cultures § Conflits 83 (2011); Ioana Cîrstocea, Delphine Lacombe, Elisabeth Marteu, eds., Globalization of Gender: Mobilizations, Frameworks of Action, Knowledge (London: Routledge, 2019).

10. For an analysis of scholarship focusing on transnational feminist activism, see Conway, "Troubling Transnational Feminism(s)." On transversal politics, see, among others, Dufour, Masson, Caouette, eds., Solidarities beyond Borders; Ioana Cîrstocea and Isabelle Giraud, eds., "Penser le pluralisme dans les mouvements féministes contemporains" [Thinking pluralism in contemporary feminist movements], thematic issue, L'Homme et la société 198, no. 4 (2015).

11. According to the most critical voices, historical feminist agendas have been coopted and depoliticized by globalized capitalism in the last decades. See Nancy Fraser, "Feminism, Capitalism and the Cunning of History," New Left Review 56 (2009), 97-117; Monique Selim and Anne Querrien, La libération des femmes, une plusvalue mondiale [Women's liberation: A global added value] (Paris: L'Harmattan, 2014).

12. Author's interviews with Nanette Funk, 13 September 2010; Joanna Regulska, 19 October 2010; Sonia Jaffe Robbins, 3 October 2010.

13. Her mother, a schoolteacher, was a communist and feminist activist, her father a business lawyer.

14. In one of our interviews (2 October 2010), Snitow described herself as "a feminist activist who had a job in the university." For Snitow's activist practice and theoretical vision, see especially the essays in her book, The Feminism of Uncertainty: A Gender Diary (Durham, NC: Duke University Press, 2015). See also Barbara Love, Feminists Who Changed America (1963-1974) (Urbana: University of Illinois Press, 2006), 433, for a short biography, as well as the August 2019 issues of Dissent, The Nation, and Jacobin for obituary notices.

15. Funk, 13 September 2010.

16. Both her grandfathers were leftist activists, and the family was strongly marked by Joseph McCarthy's red hunting (Robbins, 3 October 2010). See also Robbins, "What Did I Know and When Did I Know It?" in Red-Diapers: Growing-up on the American Left, ed. Judy Kaplan and Linn Shapiro (Urbana: University of Illinois Press, 1998), 103-109.

17. For a detailed record of her activities, see "Slavenka Drakulić," http://slavenkadraku lic.com. See also Slavenka Drakulić, How We Survived Communism and Even Laughed (London: Hutchinson, 1992). 
18. Drakulić coauthored with Rada Iveković a contribution in Robin Morgan, ed., Sisterhood Is Global: The International Women's Movement Anthology (Hartmonsworth, UK: Penguin Books, 1984). See also Chiara Bonfiglioli, Belgrade, 1978: Remembering the Conference "Drugarica Zena. Zensko Pitanje-Novi Pristup?"/"Comrade Woman: The Women's Question: A New Approach?" Thirty Years After (master's thesis, Utrecht University, 2008).

19. Joanna Regulska's full professional CV until the 2010s is available on Rutgers University's website: https://wisem.rutgers.edu/sites/default/files/resume/128cv.pdf (accessed 1 April 2020); for her later activities, see https://globalaffairs.ucdavis.edu/about/welcome/ regulska-biography (accessed 1 April 2020); cf. also Sławomira Walczewska, "Interview with Joanna Regulska," Global Feminisms Project, University of Michigan, 15 April 2005, http://hdl .handle.net/2027.42/55694.

20. Author's interview with Joanna Regulska, 19 October 2010. See also Walczewska, “Interview with Joanna Regulska."

21. In the 1990s, Regulska was involved in international projects oriented toward reforming local politics in Poland, and she promoted gender studies in Eastern Europe and the former Soviet Union.

22. See "History," Left Forum, https://leftforum.org/about-us/history-socialist-scholarsconference-left-forum (accessed 5 September 2019), on this forum of the US Left taking place since the 1960s.

23. Ann Snitow, letter to "the organizing committee in formation," 29 October 1990, signed "In sisterhood."

24. As an informal meeting of feminist activists, the conference contrasted with previous events organized by governments and international bodies. For a vivid, reflective account of the event, see Ann Snitow, "All Were Rebels: The Founding of the Network of East-West Women," Dissent, Winter 2020, 145-156. At the moment of writing, Snitow's posthumous book Visitors: An American Feminist in East Central Europe (New York: NYU Press, 2020), containing recollections of her NEWW experience, was not available to me.

25. The location of the gathering was suggested by Slavenka Drakulić: the Inter-University Center, established in Dubrovnik in the early 1970s with UN support, functioned as a hub of intellectual exchanges across the Cold War borders. See its website at http://www.iuc.hr. Nanette Funk participated in summer schools organized there in the 1970s (Funk, 13 September 2010).

26. Robin Morgan, ed., Sisterhood Is Powerful: An Anthology of Writings from the Women's Liberation Movement (New York: Random House, 1970); Morgan, Sisterhood Is Global.

27. Robbins, 3 October 2010.

28. Funk, 13 September 2010; Robbins, 3 October 2010.

29. Funk, 13 September 2010.

30. Mihaela Frunză and Theodora Eliza Văcărescu, eds., Gender and the (Post) East/West Divide (Cluj-Napoca, Romania: 2004); Nanette Funk, “Women's NGOs in Central and Eastern Europe and the Former Soviet Union: The Imperialist Criticism," in Lukić, Regulska, Zaviršek, Women and Citizenship in Eastern Europe, 265-286; Nanette Funk, "Fifteen Years of the East-West Women's Dialogue," in Living Gender after Communism, ed. Janet Elise Johnson and Jean C. Robinson (Bloomington: Indiana University Press, 2007), 203-226; Allaine Cerwonka, "Traveling Feminist Thought: Difference and Transculturation in Central and Eastern European Feminism," Signs: Journal of Women in Culture and Society 33, no. 4 (2008), 809-832, https:// doi.org/10.1086/528852; Ioana Cîrstocea, "'Between the Past and the West': Le dilemme du féminisme en Europe de l'est postcommuniste" ["Between the past and the West": Dilemma of feminism in post-communist Eastern Europe], Sociétés contemporaines 71 (2008), 7-27, https:// doi.org/10.3917/soco.071.0007.

31. Ann Snitow's notes and documents from Dubrovnik conference. 
32. Ann Snitow, letter to the Dubrovnik conference participants, 28 June 1991.

33. Letter from Sonia Jaffe Robbins to Ann Snitow, 5 February 1992.

34. NEWW Newsletter, Summer 1992.

35. "NEWW Strategic Plan, first discussion draft," 15 April 1992.

36. Convened via the telephone tree, the meetings took place once or twice a month, usually at Ann Snitow's home.

37. Letter from Vera Zolberg to Ann Snitow and Sonia Jaffe Robbins, 6 May 1992, providing feedback on NEWW's "strategic plan" discussed during the 28 April 1992 meeting.

38. Letter to NEWW's members, signed by Sonia Jaffe Robbins and Ann Snitow, 4 May 1992.

39. NEWW Newsletter, Spring 1993. At that time, NEWW was not funded and its daily running was exclusively based on donations from the private resources of its members. Several interviewees underlined repeatedly that Ann Snitow invested large amounts of personal funds in order to ensure the network's survival.

40. NEWW Newsletter, Spring 1993.

41. See Florence Howe, A Life in Motion (New York: Feminist Press, 2011), 357, and Love, Feminists Who Changed America, 281.

42. Author's correspondence with Ann Snitow, 1 July 2012.

43. Shana Penn, Solidarity's Secret: The Women Who Defeated Communism in Poland (Ann Arbor: University of Michigan Press, 2005).

44. See Shana Penn, “Women's Movements On-line: The New Post-Socialist Revolution," SAIS Review of International Affairs 16, no. 1 (1996), 125-143, doi: 10.1353/sais.1996.0017. The new technology-based feminist activism was not exceptional nor limited to NEWW, as international donors provided huge amounts of funding in order to support the participation of women from around the world in the UN-organized events; see Lisa Levenstein, "A Social Movement for a Global Age: U.S. Feminism and the Beijing Women's Conference of 1995," The Journal of American History, September 2018, 336-365, https://doi.org/10.1093/jahist/jay147, for a detailed account of such initiatives as seen from the United States.

45. Their number reached 150 by mid-1995.

46. Victoria Vrana, letter to the NEWW board, 26 February 1995.

47. Roma Ciesla, letter to the NEWW board, 22 February 1995.

48. See "Victoria Vrana," Global Philanthropy Forum, https://philanthropyforum.org/ people/victoria-vrana/, for her later professional career (accessed 13 March 2020).

49. This section of the article is based on the records of the 1995-1996 online meetings of the International Steering Committee of NEWW. See also Penn, "Women's Movement On-line."

50. A feminist economist born in Jamaica and trained at the NSSR, Williams later became a consultant for UN agencies and a board member of several international feminist organizations, such as Development Alternatives for Women for a New Era (DAWN), Association for Women's Rights in Development (AWID), and International Gender and Trade Network (IGTN).

51. Ann Snitow and Gosia (Małgorzata) Tarasiewicz, letter to the NEWW New York-area members, 26 February1997.

52. In early 1998 such echoes reached the NEWW board through correspondence with a US feminist returning from a professional mission in Hungary.

53. Focus group, 23 October 1998, Ann Snitow's notes.

54. “Organizational Development Overview," document discussed during the 23 October 1998 focus group.

55. “NEWW International Steering Committee and Strategic Planning Workshop, 4-8 November 1998, Warsaw, Post-Conference Report."

56. See "Erin M. Barclay," US Department of State (archived), https://2009-2017.state .gov/r/pa/ei/biog/bureau/217669.htm (accessed 13 March 2020), for her later career. 
57. Born in 1960, she was originally trained in English and political science.

58. Author's interview with Ann Snitow, 15 September 2010.

59. Author's interviews with Ann Snitow, 2 October 2010 and 28 October 2014. See also Ann Snitow, "Feminist Future in the Former East Bloc," in What Can We Do for Ourselves? East-European Feminist Conference, ed. Marina Blagojević, Daša Duhaček, Jasmina Lukić (Belgrade: Center for Women's Studies, Research and Communication, 1995), 141-155; Ann Snitow, "Cautionary Tales," in Lukić, Regulska, Zaviršek, Women and Citizenship, 287-297; Snitow, The Feminism of Uncertainity.

60. Conway, "Troubling transnational feminism(s)."

61. Snitow, 28 October 2014.

62. I borrow this formula from Katalin Fábián, “Disciplining the 'Second World': The Relationship between Transnational and Local Forces in Contemporary Hungarian Women's Social Movements," East European Politics 30, no. 1 (2014), 1-20, https://doi.org/10.1080/21599165 .2013.856310.

63. Masson and Paulos, "Solidarity-Building as Praxis."

64. See Jiřina Šiklova, "McDonalds, Terminators, Coca Cola Ads and Feminism?," in Bodies of Bread and Butter, ed. Susanna Trnka and Laura Busheikin (Prague: Gender Studies Centre, 1993), 7-11; Marina Blagojević, "Women and the War: The Paradox of Self-Sacrifice or the Anatomy of Passivity," in Blagojević, Duhaček, Lukić, What Can We Do for Ourselves?, 32-42. See also Biljana Kašić, "Feminist Cross-Mainstreaming within 'East-West' Mapping: A Post-socialist Perspective," European Journal of Women's Studies 11, no. 4 (2004), 473-485, https://doi .org/10.1177/1350506804046821; Ralitsa Muharska, "Silences and Parodies in the East-West Feminist Dialogue," L'Homme 16, no. 1 (2005), 36-47, https://doi.org/10.7767/lhomme.2005.16.1.36; Kornelia Slavova, "Looking at Western Feminisms through the Double Lens of Eastern Europe and the Third World," in Lukić, Regulska, Zaviršek, Women and Citizenship in Central and Eastern Europe, 245-263; Marina Blagojević, Knowledge Production at the Semi-periphery: A Gender Perspective (Belgrade: Institut za kriminološka i sociološka istrazivanja, 2009); Madina Tlostanova, "The Vanished Second World, Global Coloniality, and Decolonial Gender Agency: Why Did We Disappear, or 'Can the Post-Socialist Speak?,'" in Feminist Critical Interventions: Thinking Heritage, Decolonising, Crossings, ed. Biljana Kašić, Svetlana Slapšak, Sandra Prlenda, Jelena Petrovic (Zagreb: Center for Women's Studies, Red Athena University Press, 2013), 51-65.

65. See, among others, Mihaela Miroiu, Natalia Novikova, Angelika Psarra, Krassimira Daskalova, Harriet Evans, Elena Gapova, Jane Slaughter, Marilyn Boxer, "Forum: Is 'Communist Feminism' a Contradictio in Terminis?," Aspasia: The International Yearbook of Central, Eastern and Southeastern European Women's and Gender History 1 (2007), 197-246, and Francisca de Haan, ed., "Forum: Ten Years After. Communism and Feminism Revisited," Aspasia: The International Yearbook of Central, Eastern and Southeastern European Women's and Gender History 10 (2016), 102-168, https://doi.org/10.3167/asp.2016.100107. A recent controversy involving NEWW founding member Nanette Funk concerned the possibility of extending the definition of feminism and state feminism in order to include the socialist states' programs in support of women's emancipation. See Nanette Funk, “A Very Tangled Knot: Official State Socialist Women's Organizations, Women's Agency and Feminism in Eastern European State Socialism," European Journal of Women's Studies 21, no. 4 (2014), 344-360, https://doi.org/10.1177/1350506814539929; Kristen Ghodsee, “Untangling the Knot: A Response to Nanette Funk," European Journal of Women's Studies 22, no. 2 (2015): 248-252, https://doi.org/10.1177/1350506815571264; Funk, "(K)not so: A Response to Kristen Ghodsee," European Journal of Women's Studies 22, no. 4 (2015): 350-355, https://doi.org/10.1177/1350506815592759.

66. See Ioana Cîrstocea, "Se faire une voix: La production internationale du féminisme est-européen des années 1990-2000" [Finding one's own voice: The international making of 
East-European Feminism in the 1990s-2000s], L'Homme et la société 198 (2015), 35-56, https:// doi.org/10.3917/lhs.198.0073; Cîrstocea, La fin de la femme rouge?, chapter 5. This moment of solidarity building among ECE women was also mentioned in Jennifer Suchland, Economies of Violence: Transnational Feminism, Postsocialism and the Politics of Sex Trafficking (Durham, NC: Duke University Press, 2011), 106-107, and Ghodsee, Second World, Second Sex, 1-2.

67. Eszter Kováts, ed., Solidarity in Struggle: Feminist Perspectives on Neoliberalism in EastCentral Europe (Budapest: Friederich Ebert Stiftung, 2016).

68. This analysis applies well beyond the ECE region; cf. Bernal and Grewal, Theorizing NGOs. States, Feminisms, and Neoliberalism; Bernard Hours and Monique Selim, L'enchantement de la société civile globale: ONG, femmes, gouvernance [The spell of global civil society: NGOs, women, governance] (Paris: L'Harmattan, 2014). On ECE, see, among others: Kristen Ghodsee, "Feminism-by-Design: Emerging Capitalisms, Cultural Feminism and Women's Nongovernmental Organizations in Post-socialist Eastern Europe," Signs: Journal of Women in Culture and Society 29, no. 3 (2004), 727-753, https://doi.org/10.1086/380631; Kristen Ghodsee, "Nongovernmental Ogres? How Feminist NGOs Undermine Women in Postsocialist Eastern Europe," The International Journal of Not-for-Profit Law 8, no. 3 (2006), 44-59; Katja Guenther, "The Possibilities and Pitfalls of NGO Feminism: Insights from Post-socialist Eastern Europe," Signs: Journal of Women in Culture and Society 36, no. 4 (2011), 863-867, https://doi.org/10.1086/658504.

69. Author's interview with Ann Snitow, 10 November 2014. At the moment of my last check, NEWW has been only communicating via a Facebook page, https://www.facebook .com/NetworkOfEastWestWomen (accessed 2 September 2019), and seems to have drastically reduced its activities.

70. “. . f feeling like a child begging for money.” Robbins, 3 October 2010.

71. I borrow this formula from Nicolas Guilhot, The Democracy Makers: Human Rights and International Order (New York: Columbia University Press, 2005).

72. Snitow, 2 October 2010. 